\title{
МИСТЕЦТВОЗНАВСТВО
}

\author{
DOI: https://doi.org/10.32839/2304-5809/2021-4-92-31 \\ УДК 7.03(477.53-25)
}

Овчаренко О.I., Кравченко А.M. Національна академія образотворчого мистецтва та архітектури

\section{«САД БОГІВ» - МІСЦЕ НАРОДЖЕННЯ ТАЛАНТІВ}

\begin{abstract}
Анотація. Стаття присвячена творчості відомих художників, які почали свій творчий шлях 3 культурної спільноти під назвою «Сад Богів», яку заснував Іван Мясоєдов під Полтавою у Павленках на початку XX ст. На прикладах відомих робіт художників проаналізований зв'язок між ними у певний період часу та вплив цього осередка на подальшу їх творчість. У результаті дослідження виявлені співпадіння в образній та формальній системах творчості художників цього кола, та пов’язаність їх доль. У статті досліджуеться взаємозв'язок між відомими художниками: Іваном Мясоєдовим, Соломоном Смоляновим, Федіром Кричевським, Всеволодом Максимовичем та привертаеться увага до більш детального та поглибленого вивчення цього культурного середовища.
\end{abstract}

Ключові слова: «Сад Богів», Іван Мясоєдов, Соломон Смолянов, Федір Кричевський, Всеволод Максимович, мистецтво Полтави, культ античності, українське мистецтво на початку XX ст.

Ovcharenko Oleksiy, Kravchenko Alina National Academy of Fine Arts and Architecture

\section{«GARDEN OF THE GODS» - THE BIRTHPLACE OF TALENTS}

Summary. The article is devoted to the works of famous artists who began their creative path with the cultural community called "Garden of the Gods», which was founded by Ivan Myasoyedov near Poltava in Pavlenki in the early twentieth century and the influence of this center on their further work. As a result of the research, coincidences in the figurative and formal systems of creativity of artists of this circle, and the connection of their destinies were revealed. The article examines the relationship between famous artists: Ivan Myasoyedov, Solomon Smolyanov, Fedor Krychevsky, Vsevolod Maksimovich and draws attention to a more detailed and indepth study of this cultural environment. The period of the end of the XIX century - early twentieth century for the progress of all mankind became very rich in radical changes and transformations that affected all spheres of human activity. Among the most prominent events that contributed to the emergence and development of new artistic trends was the industrial revolution and the First World War. It was this whirlwind of events that inspired contemporary artists to go in search of new ideas, change the angle of vision, inspired the use of various techniques and materials. The Art Nouveau era is characterized as a combination of many different creative directions, the purpose of which was to move away from the literal depiction of reality in the world of human experiences and emotions. There was a difficult confrontation between generations in Ukrainian art. A difficult transition from the established manner of realist artists (represented primarily by the Society of "Wanderers») to the search for new plastic forms and methods of working with them, recourse to the symbolist methods of artistic thinking and mythology. The painting of the late nineteenth century is characterised y high detailed, enhanced decorativeness, enhanced emotionality which expressed through color and tone. «Garden of the Gods" is a unique phenomenon in Ukraine, which was founded by Ukrainian artist Ivan Myasoyedov, who was a son of Grigory Myasoedov (founder of the movement of artists "Wanderers»), in the early twentieth century. The creation of such a cultural environment was due to the confrontation of generations, differences in the vision of reference aesthetic guidelines and different worldviews between father and son. "Garden of the Gods» in Pavlenky became an original center of modern aesthetics and symbolism in the stream of new European trends and witnessed the current synchronization in the Ukrainian fine arts at the turn of the century.

Keywords: "Garden of the Gods», Ivan Myasoyedov, Solomon Smolyanov, Fedor Krychevsky, Vsevolod Maksimovich, art of Poltava, the cult of antiquity, Ukrainian art in the early twentieth century.

Постановка проблеми. Творчість та діяльність Івана Мясоєдова не можна вважати цілком вивченою. Багато 3 істориків мистецтва намагалися висвітлити його життя та творчі здобутки у своїх роботах, але майже всі публікації охоплюють матеріал лише фррагментарно. Ім'я Івана Мясоєдова на теренах України недооцінено. Для виявлення місця та значення художника в історії й розвитку культури України потрібно проводити більше поглиблених аналітичних робіт.

Аналіз останніх досліджень і публікацій. Бібліографрічна база досліджень складається зі статей та монографичної роботи Коваленко А. І. В статті Білаш К. «Федір Кричевський: 8 цікавих фрактів iз життя художника «в картинах» розглядається тіорчість та життя художника Федіра Кричевського та його взаємодія з Іваном Мясоєдовим [1]. Будяк О. «Хлопці позують на даху в костюмі Адама. Я терплю» надає в своїй роботі спогади Григорія Мясоєдова про міжособисті відносини з сином під час існування "Саду Богів» [2]. Спільна статта Курочки В., Малік К. «Полтавець Іван М'ясоєдов: бунтар-авантюрист, шпигун і художник світового значення.» в художній манері розповідає про життедіяльність Івана Мясоедова [3]. Для виявлення взаємозв'язку між Іваном Мясоєдовим та Соломоном Смоляновим була використана стаття Вікторова О. «Соломон Смолянов: Жизнь за фральшивые деньги» [4]. Творча спадщина та характеристика художника Всеволода Максимовича розглядається 
у статті Парашутова «Всеволод Николаевич Максимович / Сад Українського Модерну» [5]. Однією 3 найважливіших робіт для дослідження життедіяльності Івана Мясоєдова, та для дослідження культурного осередку "Сад Богів", на сьогоднійшній день, є монографична робота Коваленко А. I. «Иван Мясоедов - художник Серебряного века: монографрiя» [6].

Мета статті - встановити взаємозв'язок між творчим формуванням відомих художників, що приймали участь в «Саді Богів». Дослідити та проаналізувати діяльність культурного середовища. Виявити вплив художників один на одного, що відобразилося в подальшій творчості.

Виклад основного матеріалу. Період кінця XIX ст. - початку XX ст. для поступу всього людства став дуже багатим на кардинальні зміни та трансформації, які торкнулися всіх сфрер діяльності людини. До найвидатніших подій, які сприяли виникненню та розвитку нових мистецьких течій став індустріальний переворот та Перша світова війна. Саме цей вихор подій надихнув сучасних митців відправитися на пошук нових ідей, змінити кут бачення, надихнув до використання різноманітних технік та матеріалів. Добу модерну характеризують як об'єднання численної кількості несхожих між собою творчих напрямів, метою яких був відхід від буквального зображення реальності в світ людських переживань та емоцій. В українському мистецтві відбувалося важке протистояння поколінь. Складний перехід від усталеної манери художників-реалістів (представлених насамперед товариством «Передвижників») до пошуку нових пластичних форм та методів роботи 3 ними, звернення до символістських прийомів художнього мислення та до міфологізму. Для живопису кінця XIX ст. характерна висока деталізація, посилена декоративність, підсилення емоційності через колір та тон.

«Сад Богів» - це унікальне явище на теренах України, яке було засновано українським художником Іваном Мясоєдовим, сином Григорія Мясоєдова (засновником руху художників «Передвижників»), на початку ХХ століття. Створення подібного культурного середовища було обумовлено протистоянням поколінь, розбіжностями в баченні еталонних естетичних орієнтирів та різних свтоглядах між батьком та сином. Свідомість молодого художника, почуття прекрасного формуеться в час коли відроджуються Олімпійські ігри, входить у моду гімнастика, на зміну класичному балету приходить вільний танець та розвивається антикознавство [1].

Григорій Мясоєдов - дуже видатна та впливова людина в галузі мистецтва. Він був одним iз засновників Товариства передвижників. Він створив багато відомих робіт, таких як «Читання Положення 19 лютого 1861 року», «Земство обідає», «Косарі» [2]. Його особистість була дуже суперечливою та неординарною, що в спадок передалося і його сину. 3 його обличчя I. Репін писав образ царя у відомій картині «Іван Грозний і син його Іван 16 листопада 1581 року».

Наприкінщі XIX ст. Григорій Мясоєдов здійснив свою мрію та придбав маєток під Полтавою в Павленках (на той час це була окраїна міста) 3 великим плодовитим садом, парком та ставком. Вся родина переїхала до цього маєтку, але без Івана.
Іван М'ясоєдов народився 12 жовтня 1881 року. Прізвищем свого хрещеного батька Зотова - користувався у другій половині життя. Значну частину свого життя він провів в еміграції, мешкаючи в різних европейських столицях в Берліні, Брюсселі, а також в столиці князівства Ліхтенштейн Вадуці під ім'ям Свген Зотов. Де б він не жив, М'ясоєдов скрізь багато працював [3]. Він мав важке дитинство, бо батько його зневажав і вважав не своєю дитиною до вісімнадцяти років. Г. Мясоєдов віддав його на виховання до великої родини пейзажиста Олександра Кисельова у Санкт-Петербург. У нього Іван жив до семи років, поки батько не повірив в їх рідність та не забрав до маєтку в Полтаві.

У 1891 році Іван Мясоєдов починає творчий шлях у приватній художній школі, яку заснував його батько. Тут він знайомиться 3 молодим Соломоном Смоляним.

Соломон Смоляний є вихідцем 3 сім’і шойхета полтавської синагоги Ісаака Смолянова. Інтерес до малювання у Соломона, народився в Полтаві в кінщі XIX століття. Сталося це після випадкового відвідування приватної художньої школи, відкритої знаменитим живописцем Григорієм Мясоєдовим. Попри всі настанови батька бути слухняним та почитати еврейські традищіi хлопець пішов своїм шляхом, в цій школі він освоїв техніку малювання і живопису. А познайомившись з сином засновника школи, який спочатку йшов по стопах батька Іваном Мясоєдовим, Соломон став брати уроки у нього. Незважаючи на наявну різницю у віці, учень з учителем швидко знайшли спільну мову і незабаром стали друзями, яких розлучила лише революція в Російській Імперії [4].

Створення культурного середовища «Сад Богів» цілком заслуга Івана Мясоєдова. Шлях, який він пройшов до цього створення є невід'ємною частиною самого культурного середовища. Почавши свій шлях художника в Александрівському реальному училищі, не можна було припустити, що 3 таким «непоказовим» атестатом у хлопця може скластися яскраве майбутне, але Іван завжди мав свій погляд та міг його відстоювати. За пропозициею отця в 1896/97 рр. молодий полтавець поступає до відомого та пристижного Московського училища скульптури та архітектури. Існують два варіанти чого його допустили до іспитів: 1) Григорій Мясоєдов особисто звернувся у спілку, з проханням про допуск сина; 2) безпосередньо через талант Івана. Саме в цьому училище розкривається його любов до античності, міфології та культу тіла. Він почає займатися гиревим спортом та приймає участь у змаганнях 3 важкої атлетики (де також відзначився відзнаками). Маючи великий зріст (приблизно $190 \mathrm{~cm}$ ), та багато м'язів молодий Мясоєдов захоплював оточуючих людей і сам дуже пишався своєю формою. Иого мистецьке оточення вважало за успіх мати такого колоритного натурщика, бо силач мав не тільки великі та фрактурні м'язи, але й величезну харизму, міг себе гарно зарекомендувати, вмів позувати. Московське училище Іван закінчив 34 срібними медалями та свідоцтвом Некласного художника [6, с. 41]. Повертатися до Полтави він не поспішав, тому відправився у Санкт Петербург, де активно знайомився 3 членами угрупування «Мир искусства» та розвивався як спортсмен. 
Надихнувшись роботою сучасних майстрів, життям великого міста, колоритом та епотажністю людей у 1903-1907 pp. Іван Мясоєдов повертається до Полтави з чітким усвідомленням того в якому напрямку він хоче розвиватися. Оселевшись у фрлігелі в садибі в Павленках, він почав збирати у себе молодих художників та створювати живі картини на міфрологічні сюжети. Серед учасників цих дійств були відомі нині митщі: Соломон Смоляний, Федір Кричевский, Всеволод Максимович.

Окрім щоденної творчої практики в написанні пластичних оголених тіл, учасники середовища організовували розважальні дійства в саду, або оголені прогулянки по околицях. Ці події не могли не вплинути на світогляд членів "Саду Богів», бо щоб приймати себе таким як $є$, пропагуючи культ тіла потрібно переступити через комплекси та думки інших людей, з чим всі, безсумнівно, впоралися.

Кількість учасників «Саду Богів» вказати важко, бо документів про вступ до цього середовища не існувало. Однак, ми можемо зробити припущення, щодо кількості. Аналізуючи картину І. Г. Мясоєдова «Похід аргонавтів», яка була написана в період діяльності клубу. Нажаль, оригінал цієї карти не зберігся через події Другої Світової війни. Коли німці відходили, то спалили значну кількість експонатів Польтавського художнього музею. Зараз ми можемо аналізувати це полотоно по багатьом замальовкам та ескизам [Зобр. № 4]. На цьому полотні зображена велика група напівоголених людей які пливуть на кораблі. Всі постаті мають атлетичні тіла та нагадують античних героїв своїми позами. Ініціалізувати особистості майже немножливо, через те що більшість поз з відвернутими обличчями. Однак можно знайти співпадіння обрисів в ескізі до полотна «Аргонавти» та етюді «Відпочинок амазонок», що знаходиться в постійній експозиції Полтавського художнього музею ім. М. Ярошенко [Зобр. № 2].

Одним з учасників був друг Івана Мясоєдова Федір Кричевський, шляхи з яким перетнулися у Московському художньому училищі живопису, скульптури і архітектури. Вони відвідували заняття у спіль- них викладачів та разом вперше відправилися у подорож за кордон до Англії. Федір згадував, як Григорій Мясоєдов будив їх з Іваном близько шостої ранку й виганяв у сад на зарядку. Після сніданку вони по 4-5 годин без перерви писали пейзажі, натурників, етюди й портрети.

«Ваня живе у фрлігелі, де в нього постійно стримлять молоді люди - його раби і наперсники, яких він пригнічуе своєю величчю, - розповідає Григорій Мясоєдов у листі до Анастасії Кривцової. - Молодь пише в мене в саду. Хлопці позують на даху в костюмі Адама. Я терплю, бо це потрібно моєму героєві Вані. Він у позі знаменитого художника махає пензлем, іноді до ладу. Або дає своїм шакалам настанови, добродушно й солідно» [2].

Для Федора цей досвід був теж дуже корисним та плідним, бо саме в цей час він має змогу практикуватися кожного дня пишучи пластичні тіла 3 натури, та маючи нагоду писати пейзажі під керівництвом відомого передвижника Григорія Мясоєдова, прикладом його інтересу до пластики оголеного тіла і гармонії тілесних фрорм може служити робота «Натурщик. Етюд» [1] [Зобр. № 3].

Наступний 3 учасників «Саду Богів» був Соломон Смоляний. Иому не довелося стати великим живописцем, але він мав дуже великі здібності в прорисовці деталей та копіюванні. В період діяльності в "Саді Богів" він остаточно визначив свій шлях як художника, який й допоміг йому

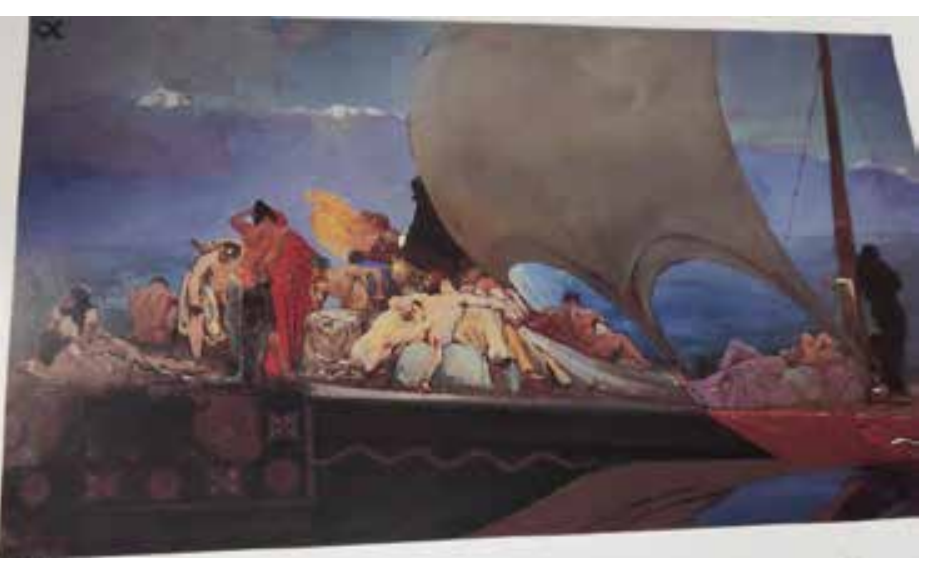

Зобр. № 1. І. Мясоедов, «Аргонавти», 1908 p.

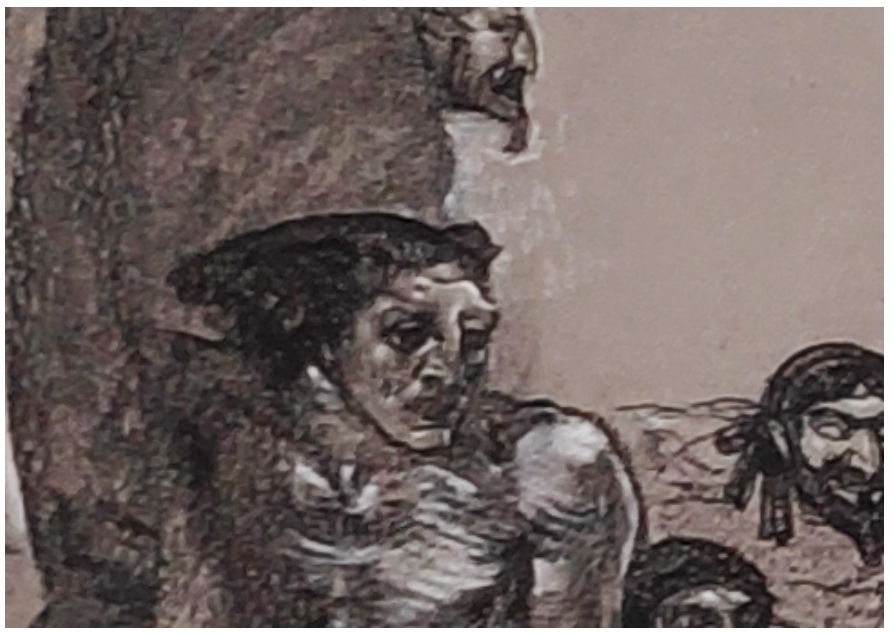

Зобр. № 2

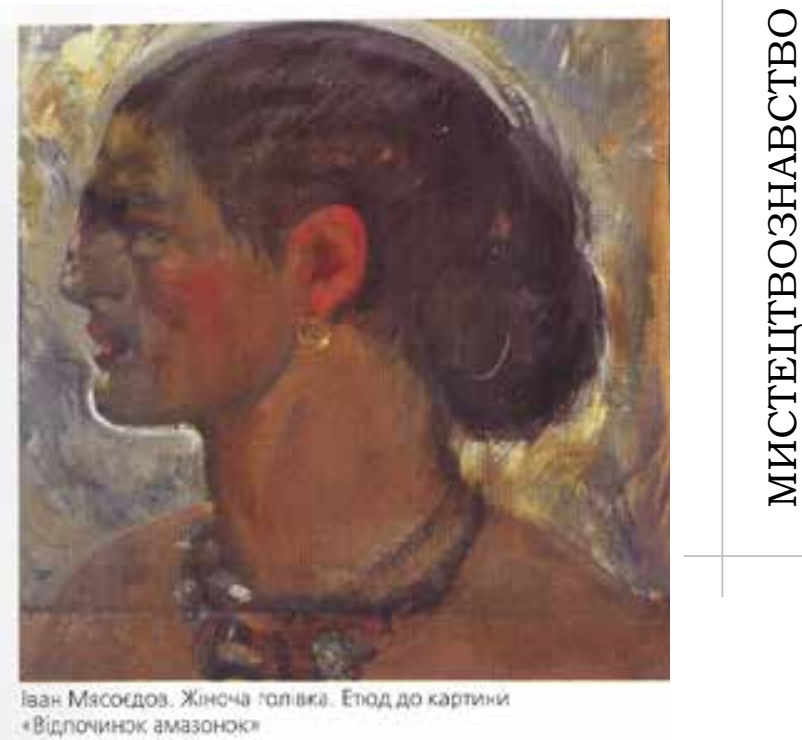




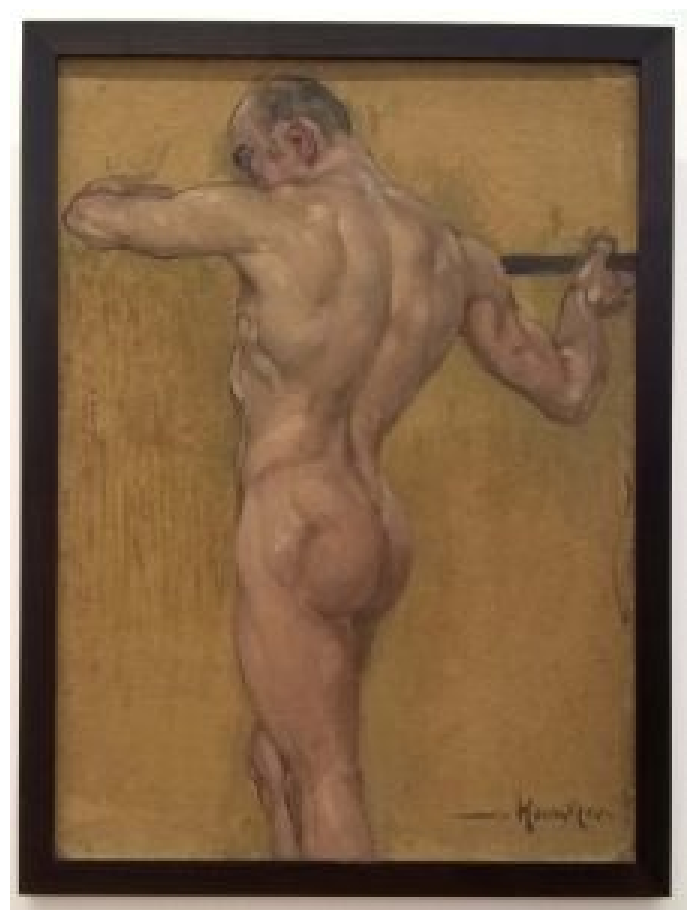

Зобр. № 3. Федір Кричевський, «Натурщик. Етюд». 1900-1910 рр.

врятуватися від страшного катаклізму, в якому загинуло понад мільйона євреїв. Батько намагався припинити його юнацькі протести спокійними повчальними бесідами, але все було марно. На Соломона махнули рукою після того, як знайшли в його кімнаті ескізи голих жінок, а він лише посміхнувся: «Це моя майбутня профресія. Я вирішив стати художником». I він ним став [4] Схожі інтереси Соломона та Івана були не тільки в живописі, саме в цей час зароджуеться пристрасть до підробки грошей. Фальшивомонетництвом хлопці почали займатися ще у Полтаві, намагаючись таким чином уникнути бідності, але вже рівня профресіоналів вони набули у $\mathrm{Hi}$ меччині. Шляхи Івана та Соломона перетиналися в майбутньому саме на цьому грунті.

Ще одним 3 видатних вихідців “Саду Богів» $є$ Всеволод Максимович, котрий також народився у Полтаві. Життя цього художника було недо-

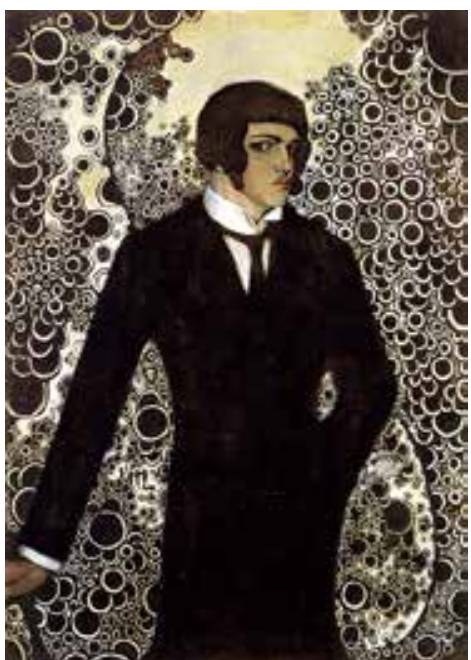

\section{I. Г. МясоєАов.}

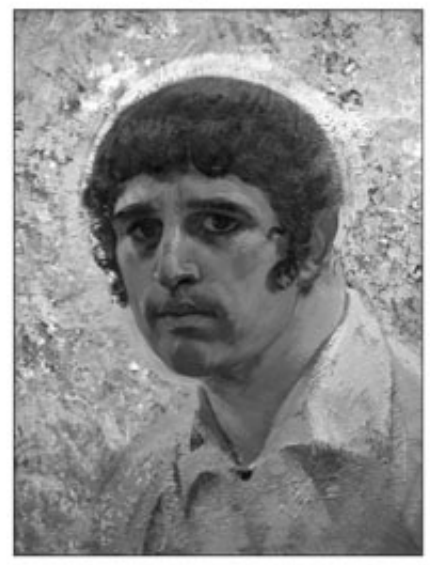

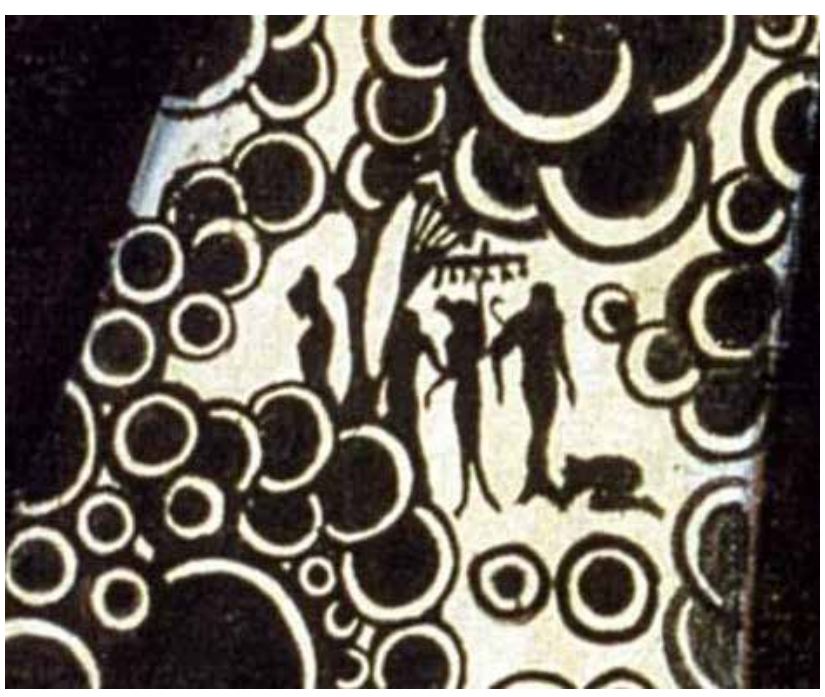

Зобр. № 4 вгим, але дуже насиченим на події. Формування як особистості та художника почалося саме 3 культурного середовища, заснованого Іваном Мясоєдовим. Всі панно та картини Всеволода Максимовича пронизані епохою модерну, символізму 3 мотивами античності. Максимович любив зображати численні гірлянди 3 рослинних візерунків, якими обплетені персонажі, схожі на олімпійських атлетів. Дуже точну характеристику цим полотнам дав у своїй статті про український модернізм «Роздоріжжя» історик Джон Боулт: «Липкі щупальця його композицій охоплюють освітлений бурштиновим світлом простір, заповнений божевільними Ефебами, хибними Аполлонами, діонісійськими німфрами і люблячими розкіш аргонавтами» [5].

Проблематично скласти уявлення про процесії, які відбувалися у «Саді Богів», бо матеріалів для дослідження не так багато. Одними з головних джерел є монографрія А. Коваленко «Иван Мясоедов - художник Серебряного века», 1998 року та книга про Івана Мясоєдова, що була випущена в Вадуці, Ліхтенштейні «IVAN MIASSOJEDOFF EUGEN ZOTOW. 1881-1953», 1997 року. Це видання багате на фрото Івана Мясоєдова, що позуе в різних образах та на репродукції картин, що були створені в цей період. Другим важливим джерелом $е$ творчі роботи учасників середовища. Найяскравішим прикладом робіт, які можна розглядати для аналізу діяльності «Саду Богів» є картини Всеволода Максимовича. Багато сюжетів повторюеться як в картинах Максимовича так і в фотографріях Мясоєдова.

Взявши до уваги одну із видатних робіт Всеволода Максимовича «Автопортрет» можна відмітити невеликий сюжет, що скривається проміж орнаментального оздоблення (Зобр. № 4), який передає атмосфреру культурного середовища, в якому він приймав участь. Такі приховані сюжети присутні на багатьох картинах і привертають увагу глядача. Це дуже цікавий аспект якому можна присвятити окреме дослідження.

На зображенні № 5 два автопортрети. Зобр. № 5 
Мясоєдова (праворуч). Здійснюючи порівняльний аналіз можна відмітити велику схожість між цими чоловіками, навіть зробити припущення, що на лівій картині зображено Мясоєдова, однак підпис Всеволода, що знаходиться ліворуч від лівого ліктя розбиває здогадки. Тим не менш, вплив Іван мав не тільки на творчу сторону Всеволода, але й на звичайну життеву, зовнішню.

Відомо, що в «Саду Богів» учасники писали один 3 одного. Як доказ цього можна розглядати, творчість Всеволода [Зобр. № 6].

Ліворуч знаходиться картина В. Максимовича «Оголені», праворуч на фото зображено Івана Мясоєдова в образі Вакха [Зобр. № 7].

Культ античності, мірологична тематика дуже вплинули на творчість Максимовича. Найвідоміші його роботи були написані саме у період членства в «Саді Богів».

Висновки. «Сад Богів» - це уні-

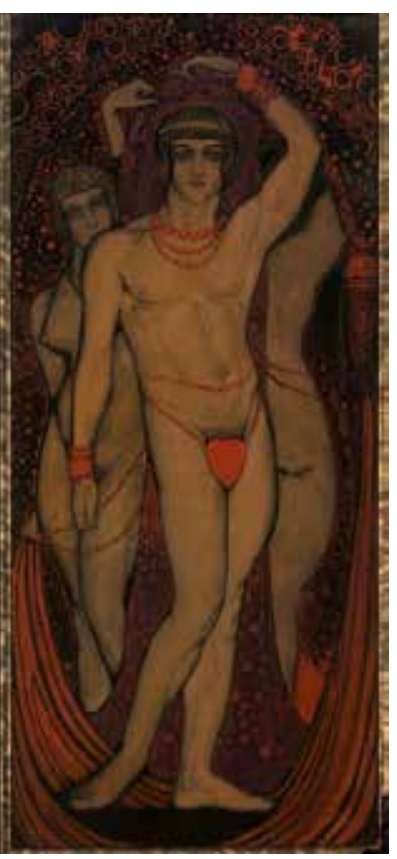

Зобр. № 6

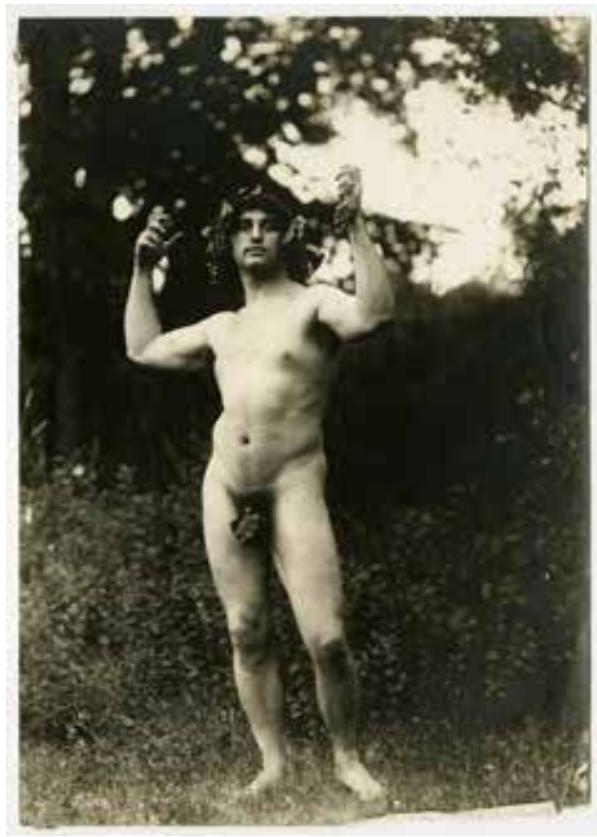

Зобр. № 7 кальне культурне середовище, яке проіснувало зовсім недовго, але сприяло формуванню відомих нині художників: Івана Мясоєдова, Соломона Смолянова, Федіра Кричевського, Всеволода Максимовича. Цей гурток вплинув на все українське мистецтво початку XX ст. та сприяв зміні світогляду молодих художників. Іван Мясоєдов, що був засновником «Саду Богів», перевернув свідомість своїх однодумців, зміг повести за собою десятки людей та надихнути художників. Четверо митців, творчий шлях яких

почався саме з «Саду Богів», реалізували себе в діяльності, яка була пов'язана з творчістю. Треба відмітити, що деякі художники вийшли 3 цього осередку із сорормованим індивідуальним впізнаваним художнім стилем (наприклад, Всеволод Максимович). «Сад Богів» у Павленках став оригінальним осередком естетики модерну та символізму у річищі нових загальноєвропейських тенденцій і засвідчив актуальну синхронізацію в українському образотворчому мистецтві зламу століть.

\section{Список літератури:}

1. Білаш К. Федір Кричевський: 8 цікавих фрактів із життя художника «в картинах». LB.ua. 2017. URL:https://lb.ua/culture/2017/07/10/371016_fedor_krichevskiy_8_interesnih.html(дата звернення: 27.04.2021).

2. Будяк О. «Хлопщі позують на даху в костюмі Адама. Я терплю». Gazeta.ua. 2019. URL: https:/gazeta.ua/articles/ history-journal/_hlopci-pozuyut-na-dahu-v-kostyumi-adama-a-terplyu/898606 (дата звернення: 27.04.2021).

3. Курочка В., Малік К. Полтавець Іван М'ясоєдов: бунтар-авантюрист, шпигун і художник світового значення. ЗМICT. URL: https://zmist.pl.ua/publications/poltavec-ivan-myasojedov-buntar-avantyurist-shpigun-ihudozhnik-svitovogo-znachennya (дата звернення: 27.04.2021).

4. Вікторов О. Соломон Смолянов: Жизнь за фральшивые деньги. Русский дом. 2016. URL: https://russiahousenews.info/ world-war-2-victory/solomon-smolyanov-falshivie-dengi (дата звернення: 27.04.2021).

5. Парашутов. Всеволод Николаевич Максимович / Сад Українського Модерну. Сад украӥнського модерну. URL: https://parafia.org.ua/SUM/biblio/творці/всеволод-николаевич-максимович/ (дата звернення: 27.04.2021).

6. Коваленко А. І. Иван Мясоедов - художник Серебряного века : монографрія. Севастополь, Крим : Мир, 1998. 204 с.

\section{References:}

1. Bilash K. (2017) Fedir Krychevskyi: 8 tsikavykh faktiv iz zhyttia khudozhnyka «v kartynakh» [Fedor Krychevsky: 8 interesting facts from the life of the artist «in the paintings»]. LB.ua (electronic journal). Available at: https://lb.ua/culture/2017/07/10/371016_fedor_krichevskiy_8_interesnih.html (accessed 27 April 2021).

2. Budiak O. (2019) «Khloptsi pozuiut na dakhu v kostiumi Adama. Ya terpliu» [«Guys posing on the roof in Adam's suit. I'm patient»]. Gazeta.ua (electronic journal). Available at: https://gazeta.ua/articles/history-journal/_hlopcipozuyut-na-dahu-v-kostyumi-adama-a-terplyu/898606 (accessed 27 April 2021).

3. Kurochka V., Malik K. Poltavets Ivan M'iasoiedov: buntar-avantiuryst, shpyhun i khudozhnyk svitovoho znachennia [«Ivan Myasoyedov from Poltava: rebel-adventurer, spy and world-famous artist»]. ZMIST (electronic journal). Available at: https://zmist.pl.ua/publications/poltavec-ivan-myasojedov-buntar-avantyurist-shpigun-ihudozhnik-svitovogo-znachennya (accessed 27 April 2021).

4. Viktorov O. (2016) Solomon Smolianov: Zhyzn za falshyvye denhy [Solomon Smolyanov: Life for fake money]. Russkyi dom (electronic journal). Available at: https://russiahousenews.info/world-war-2-victory/solomonsmolyanov-falshivie-dengi (accessed 27 April 2021).

5. Parashutov. Vsevolod Nykolaevych Maksymovych / Sad Ukrainskoho Modernu [Vsevolod Nikolaevich Maksimovich / Garden of Ukrainian Art Nouveau]. Sad ukrainskoho modernu (electronic journal). Available at: https://parafia.org.ua/SUM/biblio/творці/всеволод-николаевич-максимович/ (accessed 27 April 2021).

6. Kovalenko A. I. (1998) Ivan Miasoedov - khudozhnyk Serebrianoho veka: monohrafiia [Ivan Myasoedov - artist of the Silver Age: monograph]. Sevastopol, Crimea: Myr. 